\title{
The context of decentralised policing or local squads? The case of the Italian "Ronde"
}

\author{
Vincenzo Scalia \\ Università di Bologna, via Filippo Re 6, Bologna, Italy. \\ E-mail:vscalia70@gmail.com, vincenzo.scalia2@unibo.it. Tel: 00448451962789. \\ Accepted 5 January, 2012
}

\begin{abstract}
In summer 2009, the Italian government led by Silvio Berlusconi passed a bill which legalised the local squads or, ronde as auxiliary police forces, under the inspiration of the government partner Lega Nord. The Parliament was later to approve this bill, thus causing the indignation of that part of Italian society which saw in the ronde the proof of a populist turn of Italian society. This article will show how the ronde must be understood in the context of the deep social and political changes Italy has undergone in the last twenty years, caused both by globalisation and by the collapse of the old political class in early 1990's. It is also discussed how the gulf between police forces and population, as well as, a confused organisation of the latter, might have been one of the causes in the creation of squads. We will conclude by showing how ronde are more related to populism than they are to a change in policing.
\end{abstract}

Key words: Ronde, Italy, politics, populism, policing, Lega.

\section{INTRODUCTION}

This article will deal with the phenomenon of the Ronde, or private polices instituted by the right wing government, led by the media and football tycoon Silvio Berlusconi, which is currently ruling Italy. The concession of a legal status to private squads was inspired by the Northern League (Lega Nord), the government partner of $\mathrm{Mr}$ Berlusconi's Freedom People. The Lega is a very strong political force in Northern Italy (Diamanti, 1991), basing its electoral success on racism against both Southern Italians and migrants, who have been labelled (especially the latter) as the main threat to public order of the most developed part of the country. The political project of the Lega is based on a federalist reform of the Italian state which ensures fiscal advantages to the Northern regions, and thus gives them a way to increase their prerogative of self-government, thus, weakening the central government by increasing the powers of local administrations in public order-related matters. Policing has been part of this "devolutionist" project, as the leghisti would call it after the fashion of Scottish Nationalism.

Since 1996, the so called ronde padane (Padan squads, being Padania the name the leghisti gave to the Northern Italy), were created to patrol the territory and scare migrants, prostitutes and transsexuals away. Some of the ronde also took part, in spring 2007 , in a political rally against a nomad campsite in the outskirts of Milan, which degenerated into the throwing of Molotov bottles against the occupiers. This rally also involved the active participation of neo-fascist groups. The legalisation of the ronde as an auxiliary police force is by this token the consequence of a long time ranging moral panic which resulted from the process of globalisation. The emphasis on security issues makes up for the lack of other forms of social protection, as a consequence of welfare state roll back. The slackening of older social bonds produces the community of accomplices described by Zygmunt Bauman (2000) and, in the Italian case, developed in the context of economic changes whereby small scale industries, spread across the territory and tied to each other by an integrated productive network, made some authors speak of the end of the nation-state (Ohmae, 1996).

The social and economic changes of the last three decades have also influenced policing. Scholars have widely discussed about the changes that have occurred in the domain of public order, as far as, the role of the State is concerned. Some authors, such as Crawford (2006) argue how neo-liberalism and globalisation have changed the relationship between State and police practices in the direction of a pluralism which changed 
the role of the State. The latter has become the "steerdriver" of policing, that is the main agent of governance, thus, implying a deeper control of private spheres by the state. Other authors, such as Loader and Walker (2001), emphasized that, despite the fact that the monopoly of coercion by the State is just an ideal type; the State still has an active role in policing, especially if the latter is conceived as a public good. Jones and Newburn (2002) enshrine the changes in policing in a wider redevelopment of social control agencies, following the path undertaken by Stanley Cohen (1985) in outlining the widening of the preventive and repressive net across society. All these views share the point that, despite the fact that globalization has brought about significant changes in the role of the State, the latter still remains the main actor in policing, both when public order is enforced, and when such new tasks of police forces as the security of a community are concerned. An increased role in public order matters fills the vacuum caused by the rollback of State in economy.

This essay will be an attempt to relate this point to the Italian case. Using the assumption made by Adam Crawford (2001) that the changes in policing caused by the most recent social and economic transformations are mediated by local peculiarities, the Italian case will be analyzed under different aspects. Firstly, it will come to the fore that the Italian police forces have historically been marred by their fragmentation into different branches, and are also enforcing laws which mostly date back to the Fascist regime. It will be shown how fragmentation, authoritarian laws and personnel, have resulted in a policing style more focused on repression and the maintenance of public order. As a consequence of these aspects, Italian police reflected the contradictions of Italian society and politics, was widely unprepared to face the challenges of a global society, such as multiculturalism, eccentric urban lifestyle, and the growing demand of security of an increasingly individualised society.

The second point will analyze the ronde as the result both of police flaws and, especially, of the legitimization crisis Italian politics underwent in early 1990's, as well as, because of the destructuration of the old social and economic order. The cases of the comitati civici, of moral panic and the attempts of politicians to meet the demand of security will be discussed. It will be thus possible to see the ronde as an expressive means for the resentment of local communities, who create local squads to make up for the lack of collective identities (Ceretti, 2008). It will show how the ronde grew because the populist resentment from below was welcomed and turned into policies both by the national and by the local political class. Thirdly, this work will emphasize how both the crisis of welfare state and the public expenditures cuts have made space for the ronde, both as a private provider of security and as the Trojan horse of a new political order, either structured around the reactionary federalism of the Lega Nord, or based on a neo-fascist perspective.

The article will conclude showing how the failure of the ronde (only six were founded since the passing of the law) is related to an Italian paradox: as federalist as the Lega can be, it is currently a government party.

Therefore, the creation of the ronde is not the consequence of a mass mobilization from the bottom to the top, but rather the consequence of an old Italian habit, consisting of the use of the central government for the purpose of fulfilling local and particular interests. An attempt to outline alternatives to the ronde and to a moral panic-oriented approach will also be made.

\section{RUNNING SLOWER THAN SOCIETY: ITALIAN POLICE AFTER WORLD WAR II}

Italy's history as an independent state, dates back only to 1860, when the Kingdom of Piedmont unified the cluster of Princedoms and Kingdoms scattered throughout the peninsula and the two major isles of Sicily and Sardinia (Mack, 2007). The belated construction of an independent state, as well as, its substitution of small but locally relevant political entities, proved to be influential also for the development of national police forces. The new State had to repress the social and local revolts which spread across the country during the first year of independence to gain full control of the territory. In order for the government to achieve this aim, two main police forces were created: the Public Security (Pubblica Sicurezza), later known as State Police (Polizia di Stato) operates in the main cities to maintain public order. The Carabinieri, a branch of the army, operated in the most remote local contexts, to patrol the territory and prevent any political or social upsurge. Besides these two main police forces, Italy has had the Guardia di Finanza, a military run police which enforces the payment of taxes and represses fiscal evasions. Finally, the Polizia Municipale (City Police), which is accountable to the city council, cooperates with the other forces in ensuring public order, but especially deals with such local issues as evictions, shop licences and so on. These local police force dates back to the middle-age, when many Italian cities made up small scaled independent political entities (the Comuni).

The prerogative of the State to wield its authority across the national territory has been since the beginning mediated by the need to deal with local identities and powers, as well as, with the social unrest does to sharp social inequalities affecting the country at that time. Being the Italian independence the outcome of a passive revolution (Gramsci, 1973, II ed.), the citizens of the new State were not involved in the creation of a widely shared approach to public order. As a consequence of this, Italians have seen the police forces either as actors of repression or as the scroungers of public money. 
Additionally having a police job met the expectations of a mainly Southern Italian lower-middle class to have a safe employment, like any other branch of State administration.

The Fascist regime (1922 to 1943; Canosa, 1971) gave a further contribution to widen the gulf between the Italian population and the police forces. The repressive powers of the latter were increased, and also a paramilitary squad of Fascist Militants, the Milizia Volontaria per la Sicurezza Nazionale (Voluntary Militia for National Security) was created.

Moreover, the Fascist regime (1922 to 1943) enforced a repressive penal legislation, inspired by the idea of an "ethical state" whose task should have been that of ruling over the private life of its citizens. The changes enforced by the Fascist regime, made the relationship between police and society even worse. Not only the repression over civil liberties and social rights was legitimated, but also, the split between North and South Italy embittered the local rivalries between the two sides. The Northern Italian working-class identified the Fascist repression with the sbirri terroni (Southern Cops) who lived off the tax paid by the hard-working and antifascist Northerners. On the Southern side, the increasingly repressive attitude of the police forces resulted into a growing mistrust of the police forces by the local population. This gulf between Southern Italians and policemen widened the space for growth of the three Southern Italian criminal organizations which is the Sicilian La Cosa Nostra, the Neapolitan Camorra and the Calabrian Ndrangheta.

Post-war Italy had many problems to face. Firstly, twenty years of Fascist dictatorship and three years of a lost war, had embittered social inequalities, giving way to a widespread unrest, which result in the growth of leftwing forces, especially the Communist party (PCI), whose capital role in the antifascist resistance evolved into the construction and development of a mass party (Ginsborg, 1990). Secondly, the Communist growth scared both the conservative forces of Italy, such as the Catholic Church, the entrepreneurs and the petty bourgeoisie, and the Allied forces which have acquired the political hegemony over the country. Thirdly, the new republic (1946), born out of the II World War Two defeat, had to build its bureaucratic and administrative structure anew, and fit them into the laws of a democratic State. The electoral victory of the centre-right Christian Democratic party, limited the democratic transformation of the Italian state. The penal laws enforced under the Fascist regime were left almost unchanged, and the personnel hired during the dictatorship, in particular the directors and managers of public administration, kept their position. The police forces maintained their role of a public security-oriented body the Fascist regime had given them, so that they were mostly employed in the repression of industrial workers and peasant upsurges. As Donatella Della Porta (2003: 171) points out, post-war Italian police have operated according to the principle of the critical threshold. By this concept she means that police forces manage to negotiate public order with some social groups, whereas they exclude from negotiation other classes or groups they consider, under governmental guidance to be, a threat to public order. The Italian police forces from 1946 until 1968 focused their action mainly in the repression and prevention of the Communist threat, protecting the security of entrepreneurs and middle-classes and neglecting such other aspect of public order as organized crime (Canosa, 2003).

At end of the 1960's, the relationship between Italian police and society underwent significant changes. On the one hand, the growing force of the working class, which resulted into the electoral advancement of the Communist party and the gain of left-wing pluralities in local administration, created the space for negotiation between the workers organisation and the police forces. Moreover, the deep change Italy underwent between 1950's and 1970's also influenced the composition and the culture of police. Members of the police forces, backed by the left-wing parties, campaigned for the right to have a police trade union (Palidda, 2001), and for the de-militarisation of police forces. The outcome was the legislated reform of police, enforced by the Italian Parliament in 1981. Public Security forces turned into State Police (Polizia di Stato) and became accountable to the Ministry of Interior only. This reform was flawed in many aspects, as it did not cope with the articulation of police powers between the local and the national level, and it also left untouched the powers of the military Carabinieri force. The resistance of leading police bureaucrats, the corporate opposition by the Carabinieri, as well as, the fear of upsetting the political balance of power in the domain of public order, were among the causes that did not make a more radical reform possible. It was anyway a first, courageous attempt, which was later to remain the only one, to fit police duties to the needs of a democratic and industrialized society. On the other hand, the reform proved not to be at pace with the deeper social changes which had been affecting Italian society. An abrupt urbanisation had brought to the fore new social groups, such as women, students and a new working class of mass workers (Negri, 1995; MoroniBalestrini, 1998), whose lifestyles, expectations and values radically differed from those of the traditional working class. New social unrest broke out in 1970's Italy. The new social movements faced the repression enacted both by the police forces and by the left wing traditional organisations, such as the trade unions and the Communist party. This new wave of social conflict culminated into terrorism, and moved the critical threshold of police from the working class to the new left, the drug users and the football ultras (Scalia, 2009: 49).

As Italy became a post-industrial society since early 1980 's, police forces were seen to be unprepared to face the shift from a society organized on such social groups 
as family and class to a more hedonistic, individualised, multicultural society, which was facing for the first time in its history massive waves of immigration. The "ethic" approach of police to social problems (that is, a way of policing more inspired by the traditional catholic values than by those of a contemporary, urban, multicultural society), the lack of radical reforms, the enforcement of laws which date back to the Fascist regime, the massive wave of police repression different social groups had faced from generation to generation, made it even more difficult for the Italian police forces to keep themselves apace with the demand for public order coming from Italian society. This was the context that set the ground for the organization and development of informal policing, and would later result, particularly in Northern Italy, in the ronde.

\section{The collapse of post-war Italy and the comitati civici}

The economic changes of 1980's and 1990 are brought about a deep transformation of Italian society (Dal, 1999). As the old economy, relying on big industrial plants of large urban areas such as Milan and Turin collapsed; small scale enterprises located in small cities took over. The new economy, or post-fordism (Amin, 1994), relied on lean and just in time production, and the focus moved to communication and finance rather than in material goods. As the market has grown more and more globalised, the Italian new economy required a more flexible, unskilled and underpaid labour (Pugliese, 1995), this mainly coming from countries of the third world.

Immigration became a major issue of public order, triggering moral panic among the population of northern Italy and producing a massive demand of security which became the main issue of the political agenda. The growing economic marginality matched the changing social landscape, characterised by the presence of new, culturally different and lower class persons, such as migrants. In the old declining areas (Palidda, 1996) the presence of migrants in working class areas was perceived by the local residents as the proof of the area deterioration, as the arrival of the new residents occurred in an age of growing unemployment and big urban redevelopments which neglected urban lower-class areas (Scalia, 2005). Moreover, as the migrants were also subjected to the fluctuations of labour market, those who were unemployed and could not claim any public assistance because they lacked a legal status, turned to such illegal activities as drug-selling and prostitution.

In reaction to these changes, which had been experienced in a very short time (less than ten years), the first ronda appeared in Genoa in 1988. Local residents of the ancient city decided to group themselves and to use clubs to send foreign street pushers and prostitutes out of the area. This initiative, which was soon to draw the attention of the local media (La Repubblica, 1988), proved to be paradoxical as the ancient city of Genoa has been for centuries the bazaar (Ruggiero, 2001) district, wherein illegal activities were carried out with the informal consent and support of the local population. As some scholars were to show a few year later (Dal, 2003) the problems of local residents with foreign street criminals and that the latter ones were not seen as members of the community, as they had different social connections and expressed a different culture. The experience of the Genoan ronde was soon to be followed in Milan and in Turin, for the similar reasons of clearing working class areas of the pushers, viados (South American transsexuals) and junkies who lived and traded in the area. In this latter case, the experience proved to be more articulated, as the ronde were appointed by the comitati civici (civic committees) of local residents which were created spontaneously, that is, without any party influence, to deal with the issues of migration, crime, urban disorders. Whereas in the old industrial cities of northern Italy the ronde were created as a reaction to the degrading conditions of life of old working class, in the new industrialised areas of North-Eastern Italy (that is, the area around Veneto) they were the consequence of a moral panic which was triggered by other socio-cultural causes. Industrialization in these latter areas occurred but was not concentrated in big cities, and was spread rather in rural centres which were not prepared culturally to face the transition to a society based on industrial works and to welcome people from a different ethnic and social background (Diamanti, 1991). The birth of the Guardie Padane (Padan Guards), promoted in 1997 by the ultra-right wing mayor of Treviso Giancarlo Gentilini, and worked as an example for the creation of similar squads in the nearby areas, is more related to the resistance of a grassroots and rural culture towards the Stranger as Alfred (2000) portrayed it than to the model of the community of accomplices (Bauman, 2000) which prevailed in Milan, Turin and Genoa. North-eastern Italians, who have migrated around the world for centuries and have a strong rural background, see foreign migrants as a threat to their culture and as competitors for their recently acquired wealth, not as a threat to public order, although, their idea of order relies on a culturally and socially monolithic community (Diamanti, 1991). In any case, the idea of a sheriff-mayor brought forward by Gentilini, was to prove successful throughout Northern Italy, for reasons to be discussed.

The development and success of the ronde as a parallel police of Northern Italy would not, anyway, have been possible without such important elements as the difficulties of the Italian police we discussed in the previous paragraph. Firstly, the Italian police forces have kept following the "ethical" path opened by Fascism (Notari, 2006), that is the idea to embody the traditional Italian values. By this token, they see themselves not as a public force deputed to grant public security on behalf of the community, but rather as a body entitled to enforce 
the laws from above, which needs no other legitimization than that of the State, thus more related to a repressive model of policing than to a more co-operative one. This ethical subculture, that is an approach more focused on the protection of traditional values than on the implementation of individuals' rights, does not make the Italian police fit to cope with the conflicts and the contradictions of contemporary society more oriented to a plurality of lifestyles, cultures and expectations, and based more on consumption than on production. The government's repressive approach to such social phenomena as migration and the use of drugs contributes to worsen this aspect. Secondly, the Italian police forces suffer from the excessive overlapping of power both between different branches and between the local and national level. Nether the Police nor the Carabinieri are willing to give up part of their power to the local police forces, which have grown to become more and more recognised as the main subjects of security actions by the local population, particularly after the electoral reforms focused on the direct election of mayors and regional governors (Citta' Sicure, 1998). As Selmini (2005) points out, the new security policies enforced since 1990s give local administration (therefore local police forces) the role of co-actors of security, but in a costarring role than that of traditional police forces.

Both the ethical approach of the Italian police forces and their organisational instability, were part of the power vacuum which opened up within Italian society in early 1990's, when the Tangentopoli scandal broke out. The fall of the Berlin wall shook the foundations of the Italian political system. The end of anti-communist prejudice and the globalisation of the economy produced a political uncertainty which was soon to evolve into a massive corruption scandal involving all the main political parties of the country, especially the Christian Democrats and the Socialist Party (Nelken, 2000). This legitimisation crisis coupled with economic recession, made way for the growth of a populist approach to politics, which was based on resentment for the old politicians and on a demand for deep political and economic reforms aimed at the roll back of the so-called partitocrazia (partyocracy) or the patron-like hegemony of the parties over Italian politics and society. As the left-wing forces were experiencing a deep crisis, both because of 1989 events had deprived them of an alternative political perspective, and of massive economic transformation, the collapse of Christian Democracy had deprived Italy of a moderate political force which might have been capable of meeting the demand for change by public opinion.

This political vacuum was soon to be filled by three different new parties, all with a strong populist approach to politics and in particular to public order. The first was the Lega Nord (Northern League) which was created in 1994 by merging together the different local Lega of the single Northern Italian regions. The Lega was the first party to make profit out of the resentment of Northern
Italian against political corruption and economic crisis, both by campaigning against corruption and by promoting a law and order policy as the solution to this and other problems. Its political strategy relied on the promotion of the interests and "values" of Northern Italian people, that is of their ethic of labour and productiveness which had turned this area of the country into one of the more economically developed in the world (Bonomi, 1998). A social patchwork made of small-sized and highly productive firms, a new middle class made of independent professionals, who worked for just a contractor, had grown out of the political system which lasted until Tangentopoli. This new class composition translated its resentments and frustration both into a secessionist claim from the "unproductive" areas of the South and into a law and order approach to migration. Basically, the Northern League was filling the vacuum left by the collapse of the left wing parties and movements. Petitions to move the gypsy campsites out of the working class area marched hand in glove with an economic programme based on anti-EU and protectionist policy to protect the Northern Italian (or Padan) industry from its global competitors. This short circuit between social frustration and political populism catalysed the creation of private squads across Northern Italy, often made by militants of the Lega. The patrol of areas where migrants was supposed to be located, the spraying of Nigerian prostitutes on the train, the sit in rallies to oppose the building of mosques, became popular in Italian public opinion. The Padan Guards, usually led by Lega MPs such as Roberto Calderoli (a Minister in the former government) and Mario Borghezio were distinguished for its rude and violent approach to migrants and gypsies, but also for the refusal to negotiate. Its outcomes have often been successful, as the actions undertaken by this ronde changed the decisions of local administration, such that the construction of campsites, mosques and housings for migrants were immediately called off, and the victims of these xenophobic raids were immediately expelled, as if they were responsible for these disorders.

\section{The ronde, moral panic and politics in the "Second Republic"}

The political and economic crisis, and the consequent rise of moral panic, gave the old Neo-Fascist party, or MSI (Movimento Sociale Italiano, Italian Social Movement) the opportunity to find its legitimisation as a mainstream actor of the Italian political system. The party changed its name into Alleanza Nazionale (National Alliance, AN), and staged a two fold policy (Ignazi, 2000). On the one hand, AN promoted its new brand as the party of a modern right, accepting the Italian constitution and looking for a re-affirmation of patriotic values. On the other hand, AN became one of the most prominent moral entrepreneurs against migrants, prostitutes, drug users and no-global activists. It can be argued that the ex-neo- 
fascists promoted on a national stage the policies and practices of the Lega. AN soon rose to the fore in the public arena of the "Second Republic" political system, born after the collapse of the post-war political class (Pasquino, 1995). Both in Central and in Southern Italy, "spontaneous" committees of citizens were formed to demand more public order against the disorder brought about either by the gypsies and by the seasonal migrant workers employed in Italian agriculture. The committee was soon to promote groups of self-defense, engaged in patrolling the territory and thus, making sure that the "undesirable" persons kept themselves out of the areas where local residents lived, shopped and spent their leisure time. Unlike Northern Italy, the South has the peculiar aspect that criminal organisations military control the territory. This meant that in some areas of Southern Italy, especially in Campania (near Naples) some connections between the ronde and the local camorra (Saviano, 2008) occurred. For the mobs, who worked as labour brokers between local entrepreneurs and migrant labour, it was a chance both to gain the consent of local population and to keep migrants subjugated and prevent any claim for better work conditions.

Forza Italia, the party founded by the football and media tycoon Silvio Berlusconi, which was to merge in 2007 with AN into the new party Popolo delle Liberta' (Liberties People) as an electoral machine depending on one man, did follow the law and order policies of its two partners, though not founding civic committees and ronde. In this latter respect, other subjects proved to be particularly active, such as small neo-fascist groups as Forza Nuova, whose members come from the ranks of youth working class Italians, and often enjoyed the implicit consent of part of public opinion when burning gypsy campsites or assaulting migrants.

The birth of the ronde is therefore a phenomenon from below, drawing on the political discontent that broke out in Italy in the early 1990's and growing in the context of social fragmentation produced by global changes in the economy. The members of the civic committees and of the ronde are neither moved by a drive for a democratic management of public order, nor do they want to express an alternative form of society and social control. They are moved by the demand of security, to the extent that they feel insecure both because of their social marginality and because the presence of migrants, who epitomise this marginality. The ronde, both when they articulate the securitarian discourse (that is, when they give importance to the issues of security) and when they draw lines between the local population and the others, fit into the theoretical frame drawn by Zygmunt Bauman (2000), particularly into the concept of community of accomplices or a community which is shaped around the need to find and prosecute a scapegoat. Migrants have been part of Italian society for thirty years, and their contribution to Italian economy accounts for the $15 \%$ of Italian GNP (ISTAT, 2006). Italian society had shown a relative tolerance towards the migrants throughout the 1980s, when economy was growing and Italy could boast to have the $5^{\text {th }}$ biggest economy in the World ${ }^{1}$. Intolerance and the ronde grew out of the deep social and political crisis the country underwent since the late 1980's.

As has been constantly pointed out through this work, the ronde could have not been successful without the growing of urban security as a capital issue of the political agenda. Because the police forces were not organized and prepared to face the conflicts of post modern society, it should have been the task of politics to set more adequate standards to deal with this issue. The crisis provoked by Tangentopoli, though, left the Italian political class devoid of any charisma and legitimisation, making room for a populist transformation of the political agenda, which caused the politicians to run after the resentments and frustration of Italian society rather than try to deal with them (Dal, 1999). The police forces, by this token, were obliged to follow the same path, and this was exacerbated because their new ranks were made up of these younger generation who grew up in the context of moral panic which set in the 1990s (Palidda, 2001). As a consequence of this, the demand for security expressed by the ronde was deemed, both by the police forces and political class, as more important than the respect and implementation of civil liberties and human rights. From the middle of 1990's, the government of both political sides implemented public order policies based on the control of the so-called "dangerous classes" (Campesi, 2008), making more restrictive laws about migration, drug use and also hardening the laws about imprisonment.

As far as the first aspect is concerned, it was the centre-left government led by Lamberto Dini who passed the first restrictive bill about migrants, by introducing the expulsion for those foreigners who had committed a crime, regardless of its seriousness. It was his successor, Romano Prodi, who would have made things tougher two years later, when the new migration law was passed. This law introduced the so-called Centri di Permanenza Temporanea (CPT, Centres of Temporary Stay), where illegal migrants were jailed before being expelled from the country. The law passed in 1998 by new majority of centre-left coalition simply followed the path of the previous laws, which identified migration as the main public order problem affecting Italy and at the same time restricted the opportunities for migrants to enjoy civil, social and political rights (De Giorgi, 2001).

The second lot of public order laws was concerned about the punishment of drug users, with a first law passed in 1990 under the inspiration of the Reagan and Bush administrations' war on drugs and criminalizing drug users in the same way as dealers and pushers. It was followed in 2006 by another law, which obliges the consumers of hashish and marijuana to undergo medical treatment in community centres mostly run by Catholic organisation. It was though the third law change that

1USA, Japan, West Germany and France were the other biggest economic powers in 1980 s. 
importance for ronde. It was the centre-left majority which stayed in power from 1996 to 2001 to pass the "security package" of 2001 increasing years to be served for minor offences. Six years later, Prodi went back into power, supported by a very small majority which was to collapse two years later. As public opinion grew resentful about the government in power, the centre-left power decided to pass a bill which increased the powers of mayors for the management of public order, thus allowing city administrations to expel migrants and to re-use the ordinances, or the decrees dating back to the Fascist age which allowed administrators to implement authoritarian decisions against those individuals or social groups they deemed responsible for public disorder acts. This bill followed the media and public attention over the rape of an Italian girl by a Romanian man (La Repubblica, 2007), an episode which had provoked the beating of migrants and the aggression towards gypsy campsites by different ronde. More than one year later, after the political change of the majority, the Lega Nord Minister of Interiors Roberto Maroni had a new security bill approved. The new law legalised the ronde as an auxiliary police force that the mayor could employ to grant public order. It also created the new crime of illegal immigration and confirmed that all the gypsies should have fingerprints taken, including children, despite the protests of many humanitarian organisations (www.mininterno.it). The legalisation of the ronde upset that part of Italian society which claimed the importance of the implementation of civil liberties, and saw a parallel between the ronde and the Fascist squads of 1920's, who had been engaged in paramilitary activities before being legalised by Mussolini (Collotti, 1986).

The squad-like nature of the ronde, as important as was, forms part of the problem. In order to understand their legalization as auxiliary police forces, it is necessary to relate it to the Italian broader political context, with particular reference to the local level of government. Globalisation, for Italy, has indeed consisted of a strong delocalisation of powers, as well as with the growing demand on local authorities as the reliability of a national political class was shaken by corruption scandals and the new political forces, mainly the Lega, claimed for federalism.

\section{THE MAYOR AS A SHERIFF: THE ITALIAN WAY TO FEDERALISM}

Since the early 1980's, a discussion about massive political reforms has been going on in Italian public opinion. As the country grew more industrialised and urbanised, and new individualised lifestyles appeared, demands for new regulation of political participation, giving more power to citizens and reducing the prominent role of political parties grew stronger and stronger
(Ferrari, 2001). At the beginning, it was the new social movements of women, students and new working class who required radical changes. The withering away of radical political movements turned this request into a demand for rationalisation of the electoral system and for more powers to be given to the Prime Minister (Pasquino, 1989).

At end of 1980's, the Lega appeared as a new actor of the Italian political system. The leghisti claimed the need to undertake a federalist reform of the State, so that the wealthier areas of the country, that is, the Northern Italian regions, could spend the taxes they paid on their territory, rather than funding both the unproductive and corrupted central government and the "parasites" of Southern Italy. The outcome of these requests consisted of the reform of the electoral system both nationally and locally. Under the latter aspect, in 1990 a new bill was passed, which made the mayors, the presidents of provinces and the presidents of regions (from now on called "governors") directly elected by the voters. This electoral reform, as well as shifting the power balance on the side of the executive branch, made the local authorities more accountable to the demands of citizens, spurring a process of "localization" of Italian politics. Tangentopoli, in destroying the political fabric which existed since 1946, acted as a catalyst of this process, which was approved in 2001 by the centre-left government, in a bill that introduced fiscal federalism in Italy in the domains of health and welfare. A new more radical reform was enforced in 2008 by the current Berlusconi government under the driving inspiration of the Lega.

Both these bills were however, unclear about the articulations of powers and prerogatives between the local and the national level. Firstly, cities and regions were given the power to directly manage health and welfare, but the resources to cope with these key aspects of the life of a community were still provided by the State (Illy, 2008). Secondly, in respect to the issue of public order, despite the fact that the powers of mayors and governors were increased, not only the resources to meet this issue remained the same, but also the police forces were not re-organised accordingly. No reform, either to give more power to local police, or to reduce the prerogatives of national forces was passed. This meant that the prefetti, government officers appointed to supervise public order, and the questori, that is the local chiefs of police appointed by the central government, still have the power to manage the issue of security, public order and internal security (Selmini, 2005).

Both the welfare cuts and the economic crisis, acted in this context as the creators of a vicious circle. On the one hand, social and economic instability funnelled the social resentments into a demand for security which grew more and more xenophobic and was mainly articulated at the local range. On the other hand, both the lack of resources and the unclear balance of power between local and national authorities, made it difficult for mayors and 
governors to effectively cope with these demands, thus, making room for the ronde, as well as, encouraging populist answers by local politicians, particularly by the mayors. This occurred regardless of the political majority in office. Paradoxically, it was mostly the centre-left administrators who produced law and order outputs. The reason for this is that since the left has been devoid from 1989 on of a political project of its own, its politicians saw it as necessary to meet the populist demands to keep in touch with the traditional left strongholds. The three cases which will follow are a good demonstration of this trend.

The first case concerns Bologna, the former red stronghold of Italy, capital of the "red" region of EmiliaRomagna, whose administrators, both in a city and at a regional level, had attempted to produce an alternative view of urban security by creating the scientific committee of Città Sicure (Safe Cities), whose members were recruited among the main exponents of the Italian critical criminology, such as Massimo Pavarini (who was the head of the committee), Dario Melossi, Giuseppe Mosconi. The production of valuable scientific research by the committee, though, proved to be unsuccessful in slowing down the populist trend in this "red" region. This was shown in the results of local election of 1998 and 1999, when the cities of Parma and Bologna elected two centre-right majors who had focused their electoral campaign on urban security. Five years later, the victory of the popular trade unionist Sergio Cofferati in Bologna, seemed to have brought things back to the right track.

The "re-conquest" of Bologna by the left proved to be fallacious when the mayor sided with the demands for security coming from the civic committees and the Lega and Forza Nuova led ronde of Bologna. It all started in late 2005, when Cofferati ordered the Polizia Municipale to fine the lavavetri, that it the wind-screen washers, either foreigners of gypsies, who stand by the traffic lights and rush to wash the windscreens of cars to earn some money (La Repubblica, 2006). Cofferati claimed that the lavavetri worked for powerful criminal organisations, and asked for this reason the help of national police forces. The mayor picked the protests of civic committees over this problem, which had also caused a few intervention of the ronde in the past. He went further with his policies when, following the protests of the residents of a working class area where the Mosque of Bologna was to be built, the mayor decided to call off the construction of the Muslim building. Another decision concerned the prohibition of drinking alcoholic out on the street, thus, damaging the many pubs and osteria which earned their living mainly on this kind of sale. Cofferati used the powers the ordinance granted him, and justified his choices by arguing that it was the only way to avoid the bitter conflicts between migrants, students and the local population, as the actions of the ronde increased in that period. Unfortunately, his policies made him unpopular among the shopkeepers, who are the backbone of the
Bologna class composition and felt penalized by the antialcohol decision, forcing Cofferati not to stand for a second term as mayor.

The second case concerns the province of Milan, which was ruled between 2004 and 2009 by the ex-communist Filippo Penati. The expectations of an alternative policy which follow his victory, were soon to be disappointed in 2007 (Rapporto, 2007), when the Milanese ronde opposed to the construction of a Mosque, especially when it decided to build a new gypsy campsite in the hinterland of Milan. In this latter case, both the Lega and the Fascist ronde proved to be very active, including throwing a Molotov cocktail bomb over the provisional campsite and by beating gypsy children. Despite the fact that part of Milan civil society, mostly the section gathered around the Catholic organisations, sided with the gypsies, Penati decided to call off the campsite and to deport the nomads out of Milan, with the support of many mayors. He argued that gypsies were indeed a problem of public order and that the local population perceived them as a threat. At the end of the day, Penati also lost his office in 2009, when he was beaten by the right-wing candidate.

The third case is about a district of Padua, in an area around a street called via Anelli. This case has been analysed in a criminological book (Vianello, 2007). Many different migrant families lived in the area, most of them having a legal status and a regular job. The marginal position of the area, as well as, the fact that it was mainly a migrant settlement, attracted drug pushers and prostitutes in via Anelli, resulting in resentment of the Italian residents of the area, who created then civic committee and their ronda. Both the Lega and the far right political groups went to provide them with their support. The centre-left mayor of Padua, Flavio Zanonato, decided to manage the conflict by building a wall separating via Anelli from the rest of the area. City policemen were employed to patrol the fence, so that those ones who lived in the street could pass by showing either their ID or their Permit of Stay (in case of migrants). The result was that the wall embittered the conflict between Italian and foreigners, provoking violent actions by the ronde and reactions by the pushers and other foreigners. It went on for a few months, when all the residents of via Anelli were evicted from the area. The buildings were then to be torn down, to give way to a project of urban redevelopment promoted by a private construction company. Then it became known that this company had been attempting for years to undertake this project, with plans ready for a long time. These three cases show how the ronde are not either an attempt to decentralise policing or a phenomenon recalling the Fascist squads. Since their legalisation in summer 2009, their activity has been sensibly reduced, both because the power to appoint them as auxiliary police forces belongs to the major, and because the indignation of part of public opinion, as well as, the rivalries between the 
Lega and the neo-fascists that occurred after their legalisation has slowed down their growth. Under the first aspect, being the centre-left opposed to the current government, the mayors of such big cities as Turin, Genoa, Bologna, Florence and Naples have taken sides with the protest against police forces for the reduction of powers and resources, as well as emphasising the threat to democracy provided by such ronde as the one created by the neo-fascist Luciano Saya. Under the second aspect, the Lega wants to maintain the monopoly of the ronde, as they embody a law-and -order approach of a zero tolerance attitude to the social conflicts of contemporary Italy. For this reason, Maroni declared illegal the ronda created by Saya, and did the same with other Fascist groups. The Italian ronde are therefore related to a political populist trend, wherein the resentment from below is fostered by politicians who are eager to make up for the lack of long-term projects and gain immediate political consent. In relation to the project of a delocalised model of policing, the ronde appear by this token to be an approximated, instrumental and short term means of legitimising the interests of some political actors, mainly the Lega. This point is proved by the fact that, such reform which would go in this direction, as the reform of police forces, the re-definition of the power framework between the local and the national range are never enforced, probably because they would change a long-standing power balance. Migrants and gypsies suffer the consequences of these power conflicts, but, since they are not Italians, they do not matter to anyone.

\section{CONCLUSIONS}

This work has analysed the ronde in relation to the transformation of policing and the political crisis of the 1990's which brought about, in the West but in particularly in Italy, the rise of penal populism. We have seen how the ronde can be related to the legitimisation crisis the Italian politicians have faced in early 1990's, as well as, how the breaking up of post-war social bonds caused by globalisation have resulted into a xenophobic attitude against migrants and marginal groups, thus, giving the ronde also the peculiarity of being the expression of a community of accomplices as Zygmunt Bauman portrayed it. It has also been demonstrated that it would have not been possible for such a form of private policing to spread across the country had it not been for the backwardness of police forces in respect of training, organisation and for the gulf which existed between these organisations and local population. At the end of the day, using an ideal type, it can be argued that the ronde expressed the void of politics both from "below" (civil society) and from "above" (political parties). Their growth and eventual legalisation was only consistent with the populist need to promptly satisfy a demand of law and order, and it has nothing to do with the need to reform the police powers or to re-articulate the distribution of competences between the local and the national range of administration.

On this analysis of the situation, the solutions would appear to be obvious. Firstly, it is necessary to remove the political arena of the strong populist sentiment, such that it becomes possible to discuss how to reform police in contemporary Italian society. The second step to be taken concerns the need to enshrine any reform within a framework inspired by the human rights, as gypsies and migrant account nowadays for a consistent part of Italian population, and need to be integrated in it, so they should be an active part in all the discussions concerning public order. For this reason, a plural discussion involving those parts of civil society which are active in the promotion of human rights would be necessary. Thirdly, after 150 years of independence, it is time for Italy to get rid of duplicate police forces. It is also evident that the transformation of Italian society requires a de-localisation of powers which could make room for new spaces of pluralism and democratic participation, as well as helping Italy doing away with the Fascist legacy. It is a hard way, but it is worth trying.

\section{REFERENCES}

Balestrin N, Moroni P (1998). L'orda d'oro. 1968-1977, Feltrinelli, Milano.

Bauman Z (2001). La solitudine del cittadino globale, Feltrinelli, Milano.

Bonomi A (1998). Il capitalismo molecolare, Einaudi, Torino.

Campesi G (2008). Nuova polizia e controllo delle classi pericolose, Studi Sulla Questione Criminale, pp: 23-38.

Canosa R ( 2003). Storia della criminalità in Italia, Feltrinelli, Milano.

Canosa R (1971). La polizia in Italia, Feltrinelli, Milano.

Ceretti A (2008). Sinistra senza sinistra, Feltrinelli, Milano.

Cohen S (1985). Visions of social control, Politiy Press, London.

Collotti E (1986). Fascismo, fascismi, La Nuova Italia, Brescia.

Crawford A (2006). The new policing, Theor. Criminol. pp: 53-79.

Dal Lago A (1999). Non persone. L'esclusione dei migranti in una società globale, Feltrinelli, Milano.

Dal Lago A (2003). La città e le ombre, Feltrinelli, Milano.

Dal Lago A (2003). Un certo sguardo, Laterza, Bari.

Della PD, Reiter H (2003). Polizia e protesta, II Mulino, Bologna.

Diamanti I (1991). La Lega Nord, II Mulino, Bologna.

Ginsborg P (1991). Storia d'Italia, 1943-1990, Einaudi, Torino.

Gramsci A (1973). Quaderni dal carcere, Einaudi, Torino.

Ignazi P (2000). La destra in Italia, II Mulino, Bologna.

Jones T, Newburn T (2002). Police and Governamentality, Theor. Criminol. pp: $432-468$.

Loader J, Walker N (2002). Policing, Globalisation and the State, Theor. Criminol. pp: 79-107.

Mack SD (2007). A History of Italy, Oxford University Press, Oxford.

Negri A, Hardt M (1995). Il lavoro di Dioniso, Manifestolibri, Roma.

Nelken D (2000). The structures of legal change, Ashgate, Dartmouth.

Notari L (2006). Modello latino,_in Fuoriluogo

Palidda S (1996) La construction social de la deviance parmi les immigrès, COST-A2, Council of Europe.

Palidda S (2001). Polizia e società globale, Feltrinelli, Milano.

Pasquino G (1989). Restituire lo scettro al principe, II Mulino, Bologna.

Pasquino G (1995). Politica in Italia, Laterza, Bari.

Saviano R (2008). Gomorra, Rizzoli, Milano.

Scalia V (2005). Migranti, devianti e cittadini. Uno studio sui processi di esclusione, Franco Angeli, Milano.

Scalia V (2009) Just few rogues:football, violence and politics in contemporary Italy, Inter. Rev. Sociol. Sport, pp: 44-59. 
Alfred S (2000). The sojourner and other essays, University of Chciago Press, Chicago.

Selmini R (2005). "Policing and democracy. The experience of Città Sicure", Theor. Criminol. pp: 115-134.

Vianello F (2007). Via Anelli. Sicurezza e populismo, Carocci, Roma.

\section{Newspaper articles}

Genova dichiara guerra agli spacciatori, La Repubblica, 4/5/2008

Cofferati: le mafie dietro i lavavetri,_La Repubblica, 11/11/2005.
Guerra in via Anelli, La Repubblica, 7//2007.

\section{Sitography}

Ministero dell'Interno: www.mininterno.it 